either cardiothoracic surgery or general surgery earned during the 2 years prior to applying for recertification. SESATS and SESAPS will be the only self-instructional material allowed for credit. No Category II credits will be allowed. The Physicians Recognition Award for recertifying in general surgery will not be accepted in fulfillment of the CME requirement for recertification. The preceding information only partially outlines the CME requirements. Interested individuals should refer to the 1999 Booklet of Information for a complete description of acceptable CME credits.

Diplomates should maintain a documented list of their major cases performed during the year prior to application for recertification. This practice review should consist of 1 year's consecutive major operative experiences. If more than 100 cases occur in 1 year, only 100 should be listed.

Candidates for recertification will be required to complete both the general thoracic and the cardiac portions of the SESATS self-assessment examination. It is not necessary for candidates to purchase SESATS prior to applying for recertification since SESATS will be sent to candidates after their application has been approved.

Diplomates may recertify up to 3 years before the expiration of their certificate. Their new certificate will be dated 10 years from the time of expiration of their original certificate or most recent recertification certificate. In other words, recertifying early does not alter the 10-year validation.

Recertification is also open to Diplomates with an unlimited certificate and will in no way affect the validity of their original certificate.

The deadline for submission of applications for the recertification process is May 1 each year. A recertification brochure outlining the rules and requirements for recertification in thoracic surgery is available upon request from the American Board of Thoracic Surgery, One Rotary Center, Suite 803, Evanston, Illinois 60201 (telephone: 847-475-1520; fax: 847-475-6240; e-mail: abts_evanston@msn.com).

\title{
THE THORACIC SURGERY FOUNDATION FOR RESEARCH AND EDUCATION
}

\section{November 1999 Alley-Sheridan Scholars}

$\mathrm{T}_{\mathrm{r}}^{\mathrm{T}}$ his past fall, The Thoracic Surgery Foundation for Research and Education awarded seventeen AlleySheridan Scholarships for surgeons in the specialty to attend the November 1999 offering of the Harvard Executive Course Understanding the New World of Health Care. Those scholars are:

Mark S. Allen, MD, Rochester, Minn

William R. Berry, MD, Napa, Calif

Nora L. Burgess, MD, San Francisco, Calif

Andrea J. Carpenter, MD, Lackland AFB, Tex

David J. Cohen, MD, Fort Sam Houston, Tex
Thomas A. D'Amico, MD, Durham, NC

Richard N. Edie, MD, Philadelphia, Pa

Rafael Espada, MD, Houston, Tex

Peter J. Horneffer, MD, Towson, Md

Wade Leon Knight, MD, Temple, Tex

Leslie J. Kohmann, MD, Syracuse, $N Y$

Alexander G. Little, MD, Las Vegas, Nev

Richard J. Novick, MD, London, Ontario

Mark E. Sand, MD, Orlando, Fla

Sanjeev Sharma, MD, Tucson, Ariz

Mark S. Slaughter, MD, Oak Lawn, Ill

Scott J. Swanson, MD, Boston, Mass

\section{Kennedy School Sabbatical}

$T^{-1}$ he Thoracic Surgery Foundation for Research and Education announces that applications for a yearlong sabbatical to do graduate studies in health care policy at Harvard University's Kennedy School of Government are now available. Candidates will be accepted early on a rolling admission basis by the graduate school, and scholarships will be awarded by The Foundation's Education Committee. The Kennedy School will review completed applications for the program starting January 3,2000, and is prepared to make 
decisions on applications within two weeks of their recipt. The Foundation will make a decision on an application for Alley-Sheridan Scholarships within two weeks of its receipt to The Foundation office. If an interested surgeon has applied to The Kennedy School very early in January, it is possible to have the admissions and scholarship decisions completed by February 1. Please call Lainie Castle at The Foundation office for more information at 312-644-6610, extension 4798.

\section{Robert Wood Johnson Foundation Educational Opportunities}

$T^{1}$ he Thoracic Surgery Foundation announces two opportunities for cardiothoracic surgeons to apply for educational experiences sponsored by the Robert Wood Johnson Foundation. There are indications of interest in having cardiothoracic surgeons apply for the Clinical Scholars Program and/or the Washington, DCbased Fellowships for Mid-Career Health Professionals.

1. The Robert Wood Johnson Clinical Scholars Program is designed to allow young physicians committed to clinical medicine to acquire new skills and training in the nonbiologic sciences important to medical care systems. The program offers 18 to 24 months of graduate level study and research as part of a university-based, postresidency training program. At least $20 \%$ of the Clinical Scholars' time is spent in relevant clinical activities as part of their experiences.

The Robert Wood Johnson Foundation has supported the Clinical Scholars Program since 1973. Currently, seven institutions participate in the program and will be recruiting Scholars to begin the program in July 2000. These institutions are: the University of California, Los Angeles; the University of Chicago; the Johns Hopkins University; the University of Michigan; the University of North Carolina, Chapel Hill; the University of Washington, Seattle; and Yale University.

At each of these university sites, a study and research program is tailored to meet the Scholar's specific interests within the priority area the Scholar selects. Faculty and resources are available in a broad array of disciplines, including epidemiology, biostatistics, medical information sciences, economics, the social sciences, anthropology, history of medicine, law, ethics, and humanities. Although the programs vary in design and emphasis, each has developed core programs to intro- duce Scholars to basic nonbiologic disciplines and methods used in health care research.

The Clinical Scholars Program will give cardiothoracic surgeons research tools that can be used over their entire careers.

2. Robert Wood Johnson Health Policy Fellowsmid-career health professionals from academic and community health settings nationwide-spend nearly a year in Washington, DC, learning firsthand how the health policy process works. Fellows have an extensive orientation, which brings them into contact with key policy leaders in the nation's capital and prepares them for their 9-month work assignments with members of Congress or the executive branch. In recent years, these assignments have covered the breadth of the political spectrum in health policy-including the offices of Senators Dole (Republican-Kansas), Rockefeller (Democrat-West Virginia), Hatch (Republican-Utah), Kassebaum (Republican-Kansas), and Kerrey (Democrat- Nebraska).

The Fellows consistently report that the program had an enormous influence on their careers. Even when they do not work directly in policy afterward, they are much better able to help their colleagues and home institutions to understand the interplay of forces that are drastically changing our nation's health system. This is the pinnacle, introductory experience to how our political system works regarding health care.

Both programs are extraordinarily prestigious and will have continuing meaning for the careers of successful candidates. For further details and stipend information on these RWJ programs, contact The Thoracic Surgery Foundation offices (phone: 312-644-6610; fax: 312-527-6635; E-mail: Frank_Kurtz@ SBA.com). 